\title{
TRANSPORT INFRASTRUCTURE OF UKRAINE: THE MODERN REALITIES AND DEVELOPMENT PROSPECTS
}

\author{
Tetiana STROIKO', Vitaly BONDAR ${ }^{2}$ \\ V.O. Sukhomlynskyi National University of Mykolaiv, Ukraine
}

\begin{abstract}
The purpose of the article is to conduct a complex research of the state of transport structure of Ukraine and substantiate prospects of its development. The developed transport system and corresponding infrastructure are a guarantee of high level of the country's development, increasing the level of its investing attractiveness. Moreover, transport infrastructure serves as a uniting factor in the process of integration. Thus, the main function of transport infrastructure is the formation of external conditions for the management of economic entities. It is determined that the development of a state directly depends on how efficiently it performs management in different spheres. First of all, it concerns transport infrastructure. Today, the global trends necessitate constant perfection of management of transport infrastructure, in particular, investment attraction. The state and development level of transport infrastructure is one of the most important factors of socio-economic development of both member states of the European Union and Ukraine. Transport infrastructure occupies a services market sector with a market share of 75\%. And in the macroeconomic context, the share of transport infrastructure in the overall volume of gross domestic product of Ukraine is $7 \%$. In the modern management conditions, a negative dynamics of transportation and its share in the gross domestic product of Ukraine are determined mostly by the influence of economic crisis processes and negative state of development of transport infrastructure of the country. For the evaluation of activities of transport of Ukraine, we used the main indicators of its performance as criteria. The main criteria of performance evaluation of transport are: the volume of cargo transportation, cargo turnover, the ratio of modes of transport in cargo transportation, the volume of passenger transportation, passenger turnover, the cost of transportation, the ratio of passenger and cargo traffic in the economy. Transport, as an infrastructure branch, should provide timely and efficient cargo and passenger transportation and promote the integration of the Ukrainian economy into the European and world economic system. However, the existing unsatisfactory condition of the rolling stock of various types of transport in Ukraine causes a low level of using the potential of Ukraine as a transit state and, accordingly, reduces the competitiveness of the country's economy. Summarizing the above, it should be noted that the development of the transport infrastructure of Ukraine is largely determined by the ability of authorities to implement systemic institutional changes aimed at conducting reforms. First of all, this concerns the implementation of the policy of European integration. In particular, it is necessary to create favourable conditions for the development of entrepreneurship, to realize the power decentralization and complete the administrative and territorial reform, to ensure further liberalization of foreign economic activity and to increase the efficiency of the use of financial resources allocated by the EU to support economic reforms in our country.
\end{abstract}

Key words: transport infrastructure, European Integration, transit country, transport, cargo and passenger transportations.

JEL Classification: A20, B22, B41

\section{Introduction}

The developed transport system and corresponding infrastructure are a guarantee of high level of the country's development, increasing the level of its investing attractiveness. Moreover, transport infrastructure serves as a uniting factor in the process of integration. Thus, the main function of transport infrastructure is the formation of external conditions for the management of economic entities.

Single transport infrastructure of Ukraine is a set of different modes of transport that ensure transportation of cargo and passengers and act as a complex, which includes: railway, motor, marine, river, air, and pipeline transport including all communications, transportation

\footnotetext{
Corresponding author:

${ }^{1}$ Department of Economy and International Economic Relations, V.O. Sukhomlynskyi National University of Mykolaiv.

E-mail: tanyastroyko@gmail.com

${ }^{2}$ Department of Economy and International Economic Relations, V.O. Sukhomlynskyi National University of Mykolaiv.

E-mail: burkun@ukr.net
} 
hubs, motive power, handling equipment, devices, and facilities.

We made an attempt to conduct a complex research of the state of transport infrastructure of Ukraine and substantiate its development prospects.

\section{General state of the transport infrastructure of Ukraine}

Efficient functioning of the transport infrastructure is extremely high for the country that is geographically located in the centre of Europe (geographical centre of Europe is near Rakhiv, Zakarpattia region). Ukraine has an access to the Black and Azov Sea that increases a significance and role of the transport infrastructure, connecting the country with Mediterranean countries.

The territory of Ukraine includes the most important transportation routes linking Western Europe with the countries of Asia and the Caucasus. The connection of corresponding business entities by transport network is essential for their economic cooperation (Kyrylenko, 2016).

The state's development directly depends on how efficiently it performs management in different spheres. First of all, it concerns transport infrastructure. Today, the global trends necessitate constant perfection of management of transport infrastructure, in particular, investment attraction. The state and development level of transport infrastructure is one of the most important

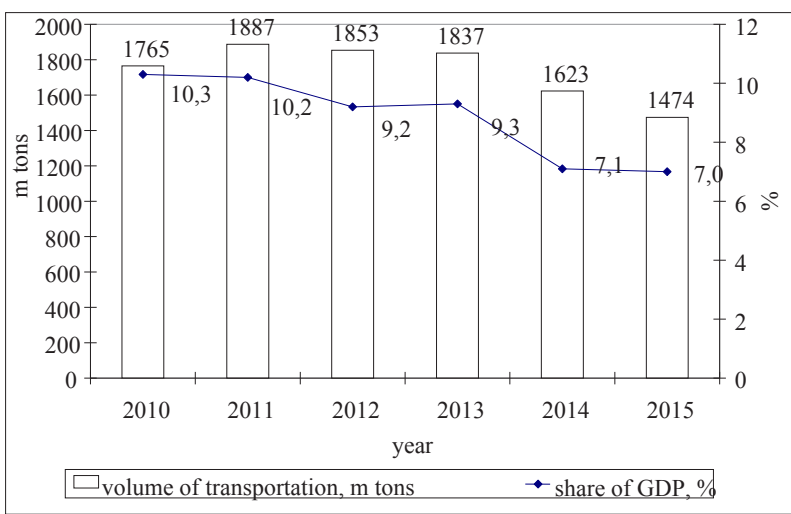

Fig. 1. Dynamics of the volume of cargo transportation in Ukraine in 2010-2015

Built by the author on data [3] factors of socio-economic development of both member states of the European Union and Ukraine (Shyba, 2016). Transport infrastructure occupies a services market sector with a market share of $75 \%$. Going to the macroeconomic context, the share of transport infrastructure in the overall volume of gross domestic product of Ukraine - 7\% (Fig. 1).

In the modern management conditions, a negative dynamics of transportation and its share in the gross domestic product of Ukraine are determined mostly by the influence of economic crisis processes and negative state of development of transport infrastructure of the country.

Transport is a set of transport and auxiliary means, connections, controls, communications, and various technical devices, mechanisms, and structures that ensure their work. Connections - roads, railways, waterways, air routes, monorail and cable cars specially adapted and equipped for traffic flow.

The transport system of Ukraine consists of different modes of transport. Each of them has its own specifics. In order to ensure the operation of the country's economy, all modes of transport should be interrelated and operate harmoniously. General transport network of Ukraine includes 21.0 thousand kilometres of railways, 159.4 thousand kilometres of highways with a hard surface, 1.6 thousand kilometres of operational river shipping routes with an access to the Azov and the Black Sea.

For the evaluation of activities of transport of Ukraine, we use the main indicators of its performance as criteria. The main criteria of performance evaluation of transport are: the volume of cargo transportation, cargo turnover, the ratio of modes of transport in cargo traffic, the volume of passenger transportation, passenger turnover, the cost of transportation, the ratio of passenger and cargo traffic in the country's economy.

The volume of transportation is the amount of cargo carried by one or another mode of transport. Table 1 provides a dynamics of cargo transportation by different modes of transport during 2000-2015. All modes of transport demonstrated a reduction in traffic in 2015 compared to 2010 that is related to objective causes of a complex economic and political situation in the country.

Table 1

Cargo transportation by modes of transport, million tons

\begin{tabular}{|l|c|c|c|c|c|c|c|c|c|c|}
\hline & \multirow{2}{*}{2000} & 2005 & \multirow{2}{*}{2010} & \multirow{2}{*}{2011} & \multirow{2}{*}{2012} & \multirow{2}{*}{2013} & \multirow{2}{*}{2014} & \multirow{2}{*}{2015} & \multicolumn{2}{|c|}{2015 in \% to } \\
\cline { 3 - 11 } & & & & & & & & 2000 & 2010 \\
\hline Transport in total & 1529 & 1805 & 1765 & 1887 & 1853 & 1837 & 1623 & 1474 & 96,40 & 83,51 \\
\hline railway & 357 & 450 & 433 & 469 & 457 & 444 & 386 & 350 & 98,04 & 80,83 \\
\hline marine & 6,3 & 8 & 4 & 4 & 4 & 3 & 3 & 3 & 47,62 & 75,00 \\
\hline river & 8,3 & 13 & 7 & 6 & 4 & 3 & 3 & 3 & 36,14 & 42,86 \\
\hline motor & 939 & 1121 & 1168 & 1253 & 1260 & 1261 & 1131 & 1021 & 108,73 & 87,41 \\
\hline air & 0 & 0,1 & 0,1 & 0,1 & 0,1 & 0,1 & 0,1 & 0,1 & x & 100,00 \\
\hline pipeline & 218 & 213 & 153 & 155 & 128 & 126 & 100 & 97 & 44,50 & 63,40 \\
\hline
\end{tabular}

Built by the author on data (Transport $i$ zviazok Ukrainy 2015) 
A growing share of road transport caused a decrease in the proportion of transportation by other modes of transport. In particular, the share of rail transport has decreased by 0.79 percentage points, pipeline by 2.09 pp, river and marine by 0.20 and 0.02 pp, respectively.

The ratio of transport modes in cargo transportation characterizes the level of territorial concentration of production and the dynamics of its change. The ratio of transport modes in cargo transportation is determined by the composition of cargo-generating sectors, the degree of territorial concentration of production.

If we consider the ratio of transport modes in Western countries, it is the following: generally, railway transport accounted for $25 \%$, motor - $40 \%$, and the rest $35 \%$ inland water, marine cabotage, and pipeline. In CIS and countries of Eastern Europe as a whole, railways are dominated in the cargo turnover -about $60 \%$ on average, whereas freight transport by road amounts only to $9 \%$. In North America, shares of railway and motor transport in cargo turnover are almost equal, whereas in Russia they amount to 46 and 9\% respectively (Lavrova, 2012). In Ukraine in 2015 , as in previous years, the biggest share in the structure of cargo turnover is occupied by railway transport (Fig. 2).

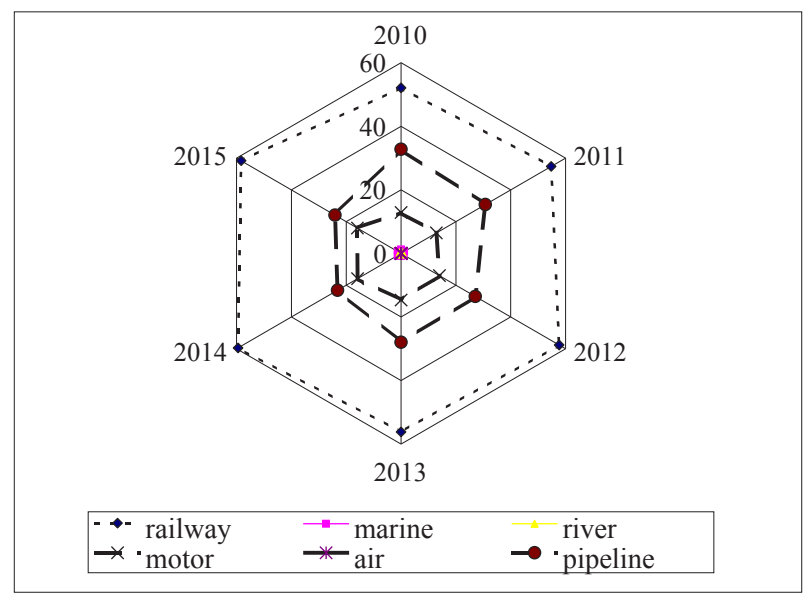

Fig. 2. Structure of cargo turnover by transport modes, \% Built by the author on data (Transport i zviazok Ukrainy 2015)
In the structure of cargo turnover by transport modes, the biggest share is occupied by railway transport, which share accounts for more than $50 \%$ in the structure of general cargo turnover. At the same time, the proportion of cargo turnover of railway transport has a tendency to increase; so, in 2015 compared to 2010, this index has increased by 6.20 pp. it is a determining mode of transport that deals with bulk cargo for the industry, construction, and agriculture.

The main cargo-generating sectors in the railway transport always were fuel and energy complex (mines, power plants, and oil refining), mining and metallurgical complex (crude ore, coke, metallurgy), and construction (sand, gravel, cement). The main cargo base for railway transport was being formed on the territory of three regions - Dnipropetrovsk, Donetsk, and Luhansk. Unfortunately, in relation to the complex political and economic situation in the east of the country, cargo base for railway transport has lost its volumes. Also, a significant proportion is occupied by cargo turnover of motor transport, which share in 2015 amounted to $15.84 \%$, which exceeds the level of the 2010 year by 3.05 pp. Road transport in Ukraine transported goods primarily for own use over short distances (average distance of transportation is $47 \mathrm{~km}$ ).

In the transport structure of Ukraine, railways are a universal mode of transport with the widest opportunities for transportation. The overall length of the railway network of Ukraine is over 21 thousand kilometres presented by six railroads that cover almost all territory of the country. Its universality can be explained by some features of our country as well as features of just railway transport. At the modern level of development of technical means, railways can be built everywhere and can ensure the shortest connection between any points of our country.

Placement of the railway network on the territory of Ukraine evolved in the course of a long historical process of development for over a hundred years and reflects the distribution of industry and environmental and economic efficiency of the use of agriculture. The densest network of railways is located in the central and

Table 2

The average distance of transportation of one ton of cargo by different modes of transport, $\mathrm{km}$

\begin{tabular}{|l|c|c|c|c|c|c|c|c|c|c|}
\hline & 2000 & 2005 & 2010 & 2011 & \multirow{2}{*}{2012} & \multirow{2}{*}{2013} & \multirow{2}{*}{2014} & \multirow{2}{*}{2015} & \multicolumn{2}{|c|}{2015 in $\%$ to } \\
\cline { 3 - 11 } & & & & & & & & & 2000 & 2010 \\
\hline Railway & 484 & 497 & 504 & 520 & 520 & 506 & 544 & 557 & 115,08 & 110,52 \\
\hline marine & 1362 & 1120 & 1271 & 1242 & 1033 & 941 & 1452 & 1173 & 86,12 & 92,29 \\
\hline in international traffic & 1632 & 1432 & 1664 & 1666 & 1301 & 1102 & 1616 & 1666 & 102,08 & 100,12 \\
\hline River & 706 & 491 & 549 & 388 & 407 & 488 & 432 & 498 & 70,54 & 90,71 \\
\hline in international traffic & 1234 & 956 & 991 & 965 & 1169 & 1021 & 955 & 1083 & 87,76 & 109,28 \\
\hline Motor & 21 & 31 & 46 & 46 & 46 & 47 & 49 & 52 & 247,62 & 113,04 \\
\hline Air & 1974 & 2658 & 4315 & 4023 & 2960 & 2753 & 3044 & 3053 & 154,66 & 70,75 \\
\hline in international traffic & 2023 & 2661 & 4328 & 4031 & 2975 & 2763 & 3060 & 3066 & 151,56 & 70,84 \\
\hline Pipeline & 859 & 932 & 895 & 883 & 870 & 886 & 821 & 830 & 96,62 & 92,74 \\
\hline
\end{tabular}

Built by the author on data (Transport i zviazok Ukrainy 2015) 
southern regions of Ukraine. The main railway lines in this part of the network interconnect the main industrial areas (Bortnyk).

One of the most important qualitative indicators on cargo transportation is the average distance of transportation as it is this indicator that makes an influence on the size of turnover and duration of delivery. Reduction of the distance of transportation reduces costs of cargo transportation and the need for transport in rolling stock. The average distance of transportation of one ton of cargo by different modes of transport is given in Table 2.

The average distance of transportation of one ton of cargo by the main modes of transport in 2015 compared to 2010 increased. In particular, the average distance of transportation of one ton of cargo by railway and motor transport increased by $10.52 \%$ and $13.04 \%$ respectively.

Transport, as an infrastructure branch, should provide timely and efficient cargo and passenger transportation and promote the integration of the Ukrainian economy into the European and world economic systems. However, the existing unsatisfactory condition of the rolling stock of various types of transport in Ukraine causes a low level of using the potential of Ukraine as a transit state and, accordingly, reduces the competitiveness of the country's economy.

\section{Development prospects of the transport infrastructure of Ukraine in terms of European integration}

The transport system of Ukraine is presented by almost all modes of the surface, water, air, and pipeline transport; however, in the development, it significantly behind the European system (Table 3 ).

Given the number of population and historical aspects of development, the most interesting for Ukraine is the positive experience of Poland in the modernization of transport infrastructure in terms of approximation to the EU. However, at the same time, it is not necessary to focus solely on operational and financial as well as management and administrative levers. Because in the process of reforming, the exceptional importance belongs to the institutional component of stimulating innovation processes in the development of transport infrastructure.

In particular, as the experience for Ukraine, one can use three key reforms, which were at one time successfully implemented by Poland. First, it concerns a liberalization of the economy and foreign economic activity that stimulated the business development and increasing its competitiveness. In this context, Poland in the period of postsocialist transformations carried out a number of important measures to encourage the establishment of businesses in all sectors of the economy (Borshchevskyi).

Among others, this concerned also transport and logistics infrastructure. In other words, economic entities that searched for opportunities for additional income and had the necessary financial resources for this could easily invest them in the implementation of relevant investment projects. At the same time, the sphere of transport and transport infrastructure was marked by high investment attractiveness, as was badly in need of modernization. Moreover, over the past decades, it faced a lack of investment resources.

The second important direction towards the transformation of transport infrastructure of Poland in terms of the country's approximation to the EU was a decentralization of power and change of administrativeterritorial structure. This allowed forming an effective system of local government that received a sufficient volume of financial and administrative and management powers to implement its tasks.

On this basis, there was formed a support system of road transport infrastructure within the local territorial communities. This gave an opportunity to essentially modernize and improve road industry, carry out a modernization of secondary roads, provide a formation of local logistical centres and creation of other objects related to the modernisation of transport infrastructure at the expense of local budgets. Moreover, financial self-sufficiency of local communities, which occurred as a result of administrative-territorial reform made, it possible to maintain the majority of transport infrastructure's objects in good condition and achieve certain synergy effects caused by the joint efforts of local government and business organizations that have implemented investment projects in the field of transport infrastructure. Consequently, the

Table 3

Comparison of transport provision of Ukraine and some countries of Europe in 2015

\begin{tabular}{|l|c|c|c|c|c|}
\hline \multicolumn{1}{|c|}{ Country } & $\begin{array}{c}\text { Area, } \\
\text { ths.sq.km }\end{array}$ & $\begin{array}{c}\text { Length of roads, } \\
\text { ths.km }\end{array}$ & $\begin{array}{c}\text { Road density, } \\
\mathrm{km} / \text { ths.sq.km }\end{array}$ & $\begin{array}{c}\text { Rail mileage, } \\
\text { ths.km }\end{array}$ & $\begin{array}{c}\text { Rail density, } \\
\mathrm{km} / \text { ths.sq.km }\end{array}$ \\
\hline Ukraine & 603,7 & 163,0 & 270,0 & 21,0 & 34,8 \\
\hline Poland & 312,6 & 426,4 & 1364,0 & 20,2 & 64,6 \\
\hline France & 551,6 & 951,7 & 1725,3 & 29,6 & 53,7 \\
\hline Germany & 357 & 647,2 & 1812,9 & 43,5 & 121,8 \\
\hline Spain & 307,6 & 683,4 & 2221,7 & 16,1 & 52,3 \\
\hline Italy & 301,2 & 487,8 & 1619,5 & 20,2 & 67,1 \\
\hline
\end{tabular}

Built by the author on data (Transport i zviazok Ukrainy 2015) 
modernization of transport infrastructure acquired a sustainable and balanced character, and its results led to positive changes in other areas of the economy.

The third direction of realization of Poland reforms, which have found its positive reflection in the modernization of transport infrastructure of the state, was the adaptation to the requirements and standards of the EU in the development of institutes of civil society. First of all, it concerns formation of a network of public organizations and other non-state institutions, which activities ensured an efficient use of tools of financial support of the EU for candidate countries. For these programs, Poland attracted significant amounts of funds for the development of various parts of the transport infrastructure.

At the modern stage, the cooperation of Ukraine and the European Union includes interchange of information and common activity: at the regional level, considering and implementing progress achieved within various transport agreements, in particular, the Eastern Partnership Transport Panel, Transport Corridor Europe - Caucasus - Asia, Baku process, and other transport initiatives.

The cooperation covers the following spheres (Uhoda pro asotsiatsiiu mizh Ukrainoiu ta Yevropeiskym Soiuzom): - development of sustainable national transport policy; - development of sectoral strategies based on the national transport policy on the motor, railway, river, marine, and air transport, as well as intermodality, taking into account terms and the main stages of implementation, administrative responsibility, and financial plans;

- development of multimodal transport network related to the Trans-European Transport Network, and infrastructural policy improvement;

- adherence to the relevant international transport organizations and agreements;

- scientific and technical cooperation and information exchange for the development and improvement of technology in the field of transport;
- promotion of the use of intelligent transport systems and information technology in the process of management and use of all modes of transport, and also support for intermodality and cooperation in using space systems and implementing business solutions that facilitate transportation.

\section{Conclusions}

Summarizing the above, it should be noted that the development of transport infrastructure of Ukraine is largely determined by the ability of authorities to implement systemic institutional changes aimed at conducting reforms.

First of all, this concerns the implementation of the policy of European integration. In particular, it is necessary to create favourable conditions for the development of entrepreneurship, to realize the power decentralization, and complete the administrative and territorial reform, to ensure further liberalization of foreign economic activity, and to increase the efficiency of the use of financial resources allocated by the EU to support economic reforms in our country.

What about Ukraine, in order to approximate the transport sector of Ukraine to the EU transport system, as well as challenges of perspective development of Europe, the main tasks should be the following: ensuring the integrity of the country; - conducting sector reforms in line with European standards; - increasing demand for transport; - the need to reduce greenhouse gas emissions; - security aspects of transport in order to reduce the number of road accidents; - the need to improve the transport efficiency; - promoting research activities; - completion of Trans-European Transport Network; improvement of the integration of road, railway, air, and water transport (maritime and inland water transport) into a single logistic chain.

\section{Referencese:}

Kyrylenko O. M. (2016). Ekonomiko-istorychni zasady formuvannia transportnoi infrastruktury Ukrainy. Problemy systemnoho pidkhodu v ekonomitsi. Vyp. 1: 7-13.

Shyba O. A. (2016). Stratehiia rozvytku transportnoi infrastruktury Ukrainy v umovakh yevrointehratsii. Prychornomorski ekonomichni studii. Vyp. 8: 35-40. [Electronic resource]. Available at: http://nbuv.gov.ua/ UJRN/bses_2016_8_9

Transport i zviazok Ukrainy 2015 (2016) [Electronic resource] [Tekst] : statystychnyi zbirnyk.

Lavrova Yu. V. (2012). Marketynh. Klasychni polozhennia i osoblyvosti zastosuvannia na transporti. Kharkiv: Izd-vo KhNADU, 227 s.

Bortnyk N. P. Rol pravovoho rehuliuvania v rozvytku transportnoi infrastruktury Ukrainy shchodo asotsiatsii z Yevropeiskym Soiuzom na prykladi Zakhidnoho [Electronic resource]. Available at: http://ena.lp.edu.ua:8080/ bitstream/ntb/34592/1/6_34-39.pdf

Borshchevskyi V. Modernizatsiia transportnoi infrastruktury v protsesi nablyzhennia do YeS: dosvid Polshchi dlia Ukrainy [Electronic resource]. Available at: http://journals.iir.kiev.ua/index.php/ec_n/article/ download/3062/2750

Uhoda pro asotsiatsiiu mizh Ukrainoiu ta Yevropeiskym Soiuzom. Hlava 7. Transport [Electronic resource]. Available at: www.kmu.gov.ua/docs/Agreement/Annex_XXVI_to_XLIII_to_Agreement.pdf 


\section{Татьяна СТРОЙКО, Виталий БОНДАРЬ \\ ТРАНСПОРТНАЯ ИНФРАСТРУКТУРА УКРАИНЫ: СОВРЕМЕННЫЕ РЕАЛИИ И ПЕРСПЕКТИВЫ РАЗВИТИЯ}

Аннотация. Целью работы является проведение комплексного исследования состояния транспортной инфраструктуры Украины и обоснование перспектив ее развития. Развитая транспортная система и соответствующая инфраструктура является залогом высокого уровня развития страны, повышая уровень ее инвестиционной привлекательности. Кроме того транспортная инфраструктура выступает объединяющим фактором в процессе интеграции. Поэтому главной функцией транспортной инфраструктуры является формирование внешних условий для хозяйствования экономических субъектов. Определено, что развитие государства напрямую зависит от того, насколько эффективно оно осуществляет управление в различных сферах. Прежде всего, это касается транспортной инфраструктуры. Сегодня мировые тенденции диктуют необходимость постоянного совершенствования управления транспортной инфраструктурой, в частности привлечение инвестиций. Состояние и уровень развития транспортной инфраструктуры является одним из самых весомых факторов социально-экономического развития как стран - членов Европейского Союза, так и Украины. Транспортной инфраструктуре принадлежит сегмент рынка услуг с рыночной долей в 75\%. А в макроэкономическом разрезе - доля транспортной инфраструктуры в общем объеме валового внутреннего продукта Украины составляет семь процентов. В современных условиях хозяйствования отрицательная динамика транспортных перевозок и их доля в валовом внутреннем продукте Украины обусловлены, в основном, влиянием экономических кризисных процессов и негативным состоянием развития транспортной инфраструктуры страны. Для оценки деятельность транспорта Украины, нами использованы основные показатели его работы в качестве критериев. Основными критериями оценки работы транспорта выступают: объем перевозок грузов, грузооборот, соотношение видов транспорта в грузовых перевозках, объем перевозок пассажиров, пассажирооборот, стоимость перевозки, соотношение пассажирских и грузовых перевозок в экономике страны. Транспорт, как инфраструктурная отрасль, должно обеспечивать своевременные и эффективные грузовые и пассажирские перевозки, содействовать интеграции экономики Украины в европейскую и мировую экономической системы. Однако существующий неудовлетворительное состояние подвижного состава различных видов транспорта в Украине вызывает низкий уровень использования потенциала Украины как транзитного государства и, соответственно, снижает конкурентоспособность экономики страны. Подытоживая изложенное, следует отметить, что развитие транспортной инфраструктуры Украины в значительной степени определяется способностью власти внедрять системные институциональные изменения, направленные на проведение реформ. Прежде всего это касается реализации политики европейской интеграции. В частности, необходимо создать благоприятные условия для развития предпринимательства, осуществить реальную децентрализации власти и завершить административно-территориальную реформу, обеспечить дальнейшую либерализацию внешнеэкономической деятельности и повысить эффективность использования финансовых ресурсов, выделяемых EC на поддержку экономических реформ в нашем государстве. 